\title{
PELAKSANAAN KOMPETENSI PEDAGOGIK GURU DI SEKOLAH DASAR
}

\author{
Rina Wahyuni \\ Teti Berliani \\ Universitas Palangka Raya, Kampus UPR Tunjung Nyaho \\ Jalan Hendrik Timang, Kota Palangka Raya, Kalimantan Tengah \\ Email: rina.wahyuni@mp.upr.ac.id
}

\begin{abstract}
Abstrak: With regard to teacher's pedagogical competence, teachers are required to be able to plan, implement and evaluate learning according to the ability of students. However, there are still teachers who have not been able to plan to learn so that they often copy-paste; the teacher has not maximally implemented PAIKEM-based learning because it still holds the old paradigm, namely the lecture. As well as the less optimal teacher in assessing learning that only focuses on cognitive aspects. This study used a qualitative approach with case study design. Data collection is done through observation, interviews, and documentation. The research results obtained, can be categorized as teacher's pedagogical competency is good enough, although it still needs guidance to teachers in improving the learning process.
\end{abstract}

Keywords: implementation, pedagogic competency, teacher

\begin{abstract}
Abstrak: Berkenaan dengan kompetensi pedagogik guru, guru dituntut mampu merencanakan, melaksanakan serta mengevaluasi pembelajaran sesuai kemampuan siswa. Namun, masih ada guru yang belum mampu merencanakan pembelajaran sehingga seringkali melakukan copy paste; guru belum maksimal melaksanakan pembelajaran berbasis PAIKEM karena masih memegang paragdigma lama, yakni ceramah. Serta kurang optimalnya guru dalam menilai pembelajaran yang hanya berfokus pada segi kognitif. Penelitian ini menggunakan pendekatan kualitatif dengan rancangan studi kasus. Pengumpulan data dilakukan dengan observasi, wawancara dan dokumentasi. Hasil penelitian yang diperoleh, dapat dikategorikan kompetensi pedagogik yang dimiliki guru sudah cukup baik, walaupun masih perlu dilakukan pembinaan kepada guru dalam perbaikan proses pembelajaran.
\end{abstract}

Kata Kunci: Pelaksanaan, Kompetensi Pedagogik, Guru

Sampai saat ini, mutu pendidikan selalu menjadi perhatian bagi para stakeholders; terlebih jika mutu itu dikaitkan dengan komponen yang bersifat human resources. Komponen yang bersifat human resources atau dalam hal ini dikategorikan tenaga pendidik (guru) adalah individu yang berinteraksi langsung dengan manusia lainnya (peserta didik); sehingga sebelum melakukan interaksi dengan para peserta didik, sudah sewajarnya seorang pendidik (guru) memiliki kemampuan dan keahlian dalam bidang pendidikan dan pengajaran. Seperti yang dikatakan oleh Imron (2011:3), bahwa peran guru yakni sebagai: (1) agen pembaruan, (2) berperan sebagai fasilitator yang memungkinkan terciptanya kondisi yang baik dari segi subjek didik untuk belajar, (3) bertanggungjawab atas terciptanya hasil belajar subjek didik, (4) dituntut menjadi contoh subjek didik dan (5) bertanggungjawab secara professional meningkatkan kemampuannya; serta (6) menjunjung tinggi kode etik profesionalnya.

Sebagai seorang pendidik, guru bertugas untuk mewariskan ilmu pengetahuan dan teknologi kepada 
para muridnya; selain itu juga, menjadi seorang guru berarti harus memiliki kemampuan dan kesiapan yang baik untuk dapat melaksanakan segala bentuk tugas dan tanggungjawab yang diemban sebagai seorang tenaga pendidik. Seperti yang terdapat dalam Undang-Undang Nomor 14 Tahun 2005 pasal 8 dikatakan bahwa "guru wajib memiliki kualifikasi akademik, kompetensi, sertifikat pendidik, sehat jasmani dan rohani, serta memiliki kemampuan untuk mewujudkan tujuan pendidikan nasional". Lebih lanjut, "kompetensi guru sebagaimana dimaksud dalam Pasal 8, yakni meliputi kompetensi pedagogik, kompetensi kepribadian, kompetensi sosial dan kompetensi professional yang diperoleh melalui pendidikan profesi". (Undang-Undang Nomor 14 Tahun 2005 tentang Guru dan Dosen).

Berkenaan dengan kompetensi pedagogik yang menjadi salah satu kompetensi yang diprasyaratkan dalam Undang-Undang tersebut, sangatlah penting bagi seorang tenaga pendidik untuk mengembangkan dan meningkatkan kualitas kompetensi dirinya. Seperti yang dikemukakan oleh Indriani (2015), kompetensi pedagogik merupakan kemampuan guru dalam mengelola pembelajaran peserta didik dengan berbasis pendekatan yang bersifat mendidik, sehingga melaksanakan fungsi profesionalnya dengan lebih efektif. Sejalan dengan itu, Saryati (2014) mengungkapkan definisi kompetensi pedagogik secara lebih kompleks sebagai berikut "Kompetensi pedagogik guru merupakan kemampuan guru dalam pengelolaan pembelajaran peserta didik yang sekurang-kurangnya meliputi: pemahaman wawasan atau landasan kependidikan, pemahaman terhadap peserta didik, pengembangan kurikulum/ silabus, perancangan pembelajaran, pelaksanaan pembelajaran yang mendidik dan dialogis, pemanfaatan teknologi pembelajaran, evaluasi hasil belajar, serta pengembangan peserta didik untuk mengaktualisasikan berbagai potensi yang dimilikinya".

Dari penjelasan tersebut, sangatlah jelas bahwa seorang guru harus memiliki kemampuan dalam melaksanakan tugas kependidikannya secara professional; sehingga profesi seorang guru bukanlah pekerjaan yang sederhana, karena guru merupakan ujung tombak dalam tercapainya tujuan pembelajaran yang ada di sekolah. Guru berperan sebagai pengelola pembelajaran, bertindak selaku fasilitator yang berusaha menciptakan pembelajaran yang efektif, mengembangkan bahan pelajaran dengan baik dan meningkatkan kemampuan peserta didik untuk menyimak pelajaran dan menguasai tujuantujuan pendidikan yang harus mereka capai. Sehingga dalam melaksanakan tugasnya, seorang guru harus mampu dalam: (a) menyusun rencana pembelajaran; (b) melaksanakan rencana pembelajaran yang telah dibuat; serta (c) melakukan evaluasi terhadap proses dan hasil belajar peserta didik. Hal ini jelas menuntut perubahan-perubahan dalam pengorganisasian kelas, pengelolaan kelas, penggunaan metoda mengajar, strategi belajar mengajar, maupun sikap dan karakteristik guru dalam mengelola proses belajar mengajar. Seperti yang dikemukakan oleh Slamet dalam Sagala (2013) bahwa kompetensi pedagogik yang harus dimiliki oleh seorang guru, yakni: (1) berkontribusi dalam pengembangan kurikulum yang terkait dengan mata pelajaran yang diajarkan, (2) mengembangkan silabus mata pelajaran berdasarkan standar kompetensi (SK) dan kompetensi dasar (KD), (3) merencanakan rencana pelaksanaan pembelajaran (RPP) berdasarkan silabus yang telah dikembangkan, (4) merancang manajemen pembelajaran dan manajemen kelas, (5) melaksanakan pembelajaran yang pro perubahan (aktif, kreatif, inovatif, efektif, dan menyenangkan), (6) menilai hasil belajar peserta didik secara otentik, (7) membimbing peserta didik dalam berbagai aspek, dan (8) mengembangkan profesionalisme diri sebagai guru.

Akan tetapi, kenyataan di lapangan masih bertolak belakang dengan apa yang seharusnya. Hal ini dibuktikan dengan masih seringnya ditemukan guru-guru yang belum maksimal bahkan kurang mampu dalam merencanakan proses pembelajaran, melaksanakan proses pembelajaran dengan baik serta melakukan evaluasi terhadap proses pembelajaran dan hasil belajar siswa itu sendiri. Seperti halnya dalam: (1) merancang rencana pelaksanaan pembelajaran (RPP), masih sering ditemukan guru-guru yang RPP nya adalah hasil dari copy paste internet, bukan hasil rancangan sendiri; guru masih terlihat kebingungan bahkan kesulitan dalam menyusun rencana kegiatan pembelajaran yang akan mereka lakukan di dalam kelas; (2) guru masih belum maksimal dalam melaksanakan pembelajaran, terlebih pembelajaran yang berbasis PAIKEM. Guru masih menggunakan paradigma lama yakni melaksanakan pembelajaran hanya dengan memberikan materi (metode ceramah) sepanjang pembelajaran di kelas. Masih ditemukan guru-guru yang hanya menginginkan siswa yang mendengarkan penjelasan dari guru 
tanpa adanya interaksi timbal balik antara siswa kepada guru (komunikasi satu arah); (3) dalam melaksanakan pembelajaran, guru jarang menggunakan media sebagai alat bantu dalam memberikan materi pelajaran kepada siswa; sehingga siswa terlihat kurang bersemangat dan termotivasi dalam mengikuti pembelajaran yang diberikan guru; (4) guru jarang melakukan pembimbingan kepada siswa terlebih saat siswa sedang menyelesaikan tugas yang diberikan oleh guru; serta (5) guru masih belum optimal dalam melakukan evaluasi terhadap hasil belajar siswa, yang hanya dinilai dari segi kuantitatif saja tanpa mampu mendeskripsikan secara kualitatif perolehan hasil belajar pada masing-masing peserta didik. Penekanan penilaian yang dilakukan guru hanya sebatas ranah kognitif siswa saja, tanpa melihat segi afektif dan psikomotorik peserta didik.

Hal ini tentu sangat bertolak belakang dengan kompetensi pedagogik yang harus dimiliki oleh seorang guru, dimana sebagai seorang guru harus memiliki kemampuan untuk merancang rencana pembelajaran, melaksanakan pembelajaran dengan aktif dan menilai proses serta hasil dari pembelajaran tersebut. Seperti hasil penelitian terdahulu yang dikemukakan Baharudin (dalam Khofiatun dkk, 2016) bahwa "kompetensi pedagogik guru diukur dari kemampuan membuat perencanaan pembelajaran, pelaksanaan pembelajaran, dan penilaian proses dan hasil belajar yang didalamnya memiliki karakteristik dari Kurikulum yang berlaku". Lebih lanjut, Depdiknas (2004:9) menyebutkan kompetensi pedagogik adalah kompetensi pengelolaan pembelajaran.

Selain itu, Sagala (dalam Jawing dkk, 2011) menegaskan kompetensi pedagogik merupakan kemampuan dalam mengelola peserta didik yang meliputi (1) pemahaman wawasan guru akan landasan dan filsafat pendidikan, (2) guru memahami potensi dan keragaman peserta didik, sehingga dapat didesain strategi pelayanan belajar sesuai keunikan masing-masing peserta didik, (3) guru mampu mengembangkan kurikulum/silabus baik dalam bentuk dokumen maupun implementasi dalam bentuk pengalaman belajar, (4) guru mampu menyusun rencana dan strategi pembelajaran berdasarkan standar kompetensi dan kompetensi dasar, (5) mampu melaksanakan pembelajaran yang mendidik dengan suasana yang dialogis dan interaktif, sehingga pembelajaran menjadi aktif, inovatif, kreatif, efektif, dan menyenangkan, (6) mampu melakukan evaluasi hasil belajar dengan memenuhi prosedur dan standar yang dipersyaratkan, dan (7) mampu mengembangkan bakat dan minat peserta didik melalui kegiatan ekstrakurikuler untuk mengaktualisasikan berbagai potensi yang dimiliki.

Sehingga dengan demikian, sudah selayaknya seorang pendidik (guru) memiliki kemampuan dalam merencanakan pembelajaran yang akan mereka lakukan di dalam kelas, melaksanakan pembelajaran yang memberikan kesempatan sebesar-besarnya pada peserta didik untuk mampu mengeksplorasi kemampuan dan keterampilan yang ada dalam diri mereka, serta melakukan evaluasi yang tidak hanya berfokus pada satu aspek yaitu kognitif, melainkan juga mengevaluasi aspek afektif dan psikomotorik dari peserta didik.

\section{METODE}

Penelitian ini menggunakan pendekatan kualitatif dengan rancangan penelitian menggunakan studi kasus. Studi kasus yang pada hakekatnya meneliti kasus, dimana kasus tersebut diperlukan dan penting untuk menguji suatu teori yang telah tersusun dengan baik. Studi kasus juga dimaknai kasus organisasi, yaitu studi kasus untuk mendapatkan informasi tentang keterangan-keterangan organisasi dimana peneliti ingin mengetahui bagaimana kehidupan orang-orang dalam organisasi tersebut. Penelitian dilakukan di SDN 5 Menteng Kota Palangka Raya.Penentuan informan dilakukan dengan teknik pengambilan sampel secara purposive sampling dan snowball sampling dengan maksud agar diperoleh data dan informasi dari orang-orang yang benar-benar mengetahui secara mendalam terkait fokus penelitian sehingga data yang diterima dapat lebih akurat.

Dari informan pertama, maka akan berkembang ke informan kedua dan seterusnya sehingga diibaratkan seperti bola salju. Hal itu sejalan dengan yang dikatakan oleh Ulfatin (2014:181), begitu informan kunci pertama diwawancarai secukupnya, ia diminta untuk menunjukkan satu atau lebih sumber lain yang dianggapnya memiliki informasi yang dianggap relevan dan memadai, sehingga dapat dijadikan sebagai informan berikutnya. Dari informan kedua yang ditunjuk oleh informan pertama, kemudian ia diminta untuk menyebutkan sumber lain yang dapat dijadikan informan berikutnya lagi. Dengan cara inilah, informasi yang diperoleh peneliti menjadi semakin besar dengan 
melibatkan beberapa orang yang menurut Bogdan dan Biklen (1992) diibaratkan seperti bola salju (snowball sampling). Teknik pengumpulan data yang digunakan adalah (a) observasi, (b) wawancara mendalam, dan (c) studi dokumentasi. Informasi yang terkumpul dari ketiga teknik tersebut dianalisis secara berulang dengan menggunakan alur pola interaktif

Analisis data penelitian Miles dan Huberman yang meliputi reduksi data, penyajian data, dan penarikan kesimpulan. Pengecekan kredibilitas data dilakukan dengan teknik triangulasi (sumber dan teknik/metode), member checks, dan kecukupan bahan referensi; pengecekan dependabilitas data penelitian dilakukan oleh peneliti mulai dari melakukan penelitian, penyusunan transkrip wawancara sampai dengan penulisan laporan hasil penelitian dan pelaksanaan penelitian sesuai dengan jadwal yang telah disepakati bersama; dan pengecekan konfirmabilitas digunakan untuk melihat bahwa hasil penelitian yang dilakukan menunjukkan adanya proses penelitian di lapangan.

\section{HASIL}

Hasil penelitian yang diperoleh terkait pelaksanaan kompetensi pedagogik guru sekolah dasar, yaitu: pertama, kemampuan guru dalam merancang/ merencanakan RPP menunjukkan: (1) sebelum melaksanakan pembelajaran di kelas, guru telah menyusun dan merencanakan Rencana Pelaksanaan Pembelajaran (RPP), (2) RPP merupakan salah satu aspek penting yang harus disusun oleh guru sebelum melaksanakan proses pembelajaran karena RPP merupakan pedoman atau panduan bagi guru dalam melaksanakan proses pembelajaran agar terarah dan tujuan pembelajaran dapat tercapai dengan optimal, serta (3) guru sudah merencanakan strategi pembelajaran yang variatif sesuai dengan konteks materi ajar yang akan dipelajari.

Kedua, kemampuangurumengimplementasikan pembelajaran yang berbasis PAIKEM menunjukkan: (1) guru melakukan kegiatan apersepsi di awal proses pembelajaran dalam rangka mengetahui sejauhmana ingatan peserta didik terhadap materi pelajaran yang dtelah dijelaskan sebelumnya serta mengaitkannya dengan materi ajar yang akan dipelajari berikutnya, (2) menganalogikan materi pelajaran secara sederhana dengan mengaitkannya dengan kenyataan dalam kehidupan sehari-hari siswa, (3) penggunaan dan pemanfaatan media serta alat peraga dalam melaksanakan pembelajaran sesuai dengan materi ajar yang diberikan, dan (4) guru mengkondisikan perhatian siswa dengan menggunakan teknik senam ingatan.

Ketiga, kemampuan guru dalam mengevaluasi hasil belajar yang sesuai dengan kemampuan peserta didik menunjukkan: (1) guru memberikan evaluasi sesuai dengan yang telah direncanakan dalam RPP, (2) bentuk dan jenis tes evaluasi yang digunakan bersifat variatif sesuai dengan konteks materi pelajaran yang diberikan, seperti soal-soal latihan, tugas dan lembar kerja siswa (LKS), (3) hasil evaluasi yang diberikan kepada peserta didik langsung diperiksa secara bersama-sama antara guru dan peserta didik, serta (4) hasil evaluasi yang diberikan kepada peserta didik dijadikan feedback dalam pemberian pembelajaran selanjutnya.

\section{PEMBAHASAN}

Hasil penelitian pada poin pertama yang berkenaan dengan kemampuan guru dalam merancang/ merencanakan RPPsejalan dengan pendapat Wahyuni dan Ibrahim (2012) yang mengungkapkan perencanaan memegang peranan penting dalam setiap kegiatan, termasuk dalam sebuah pembelajaran. Dalam kaitannya dengan pembelajaran, yang dimaksud dengan perencanaan pembelajaran adalah proses penyusunan berbagai keputusan pembelajaran yang akan dilaksanakan dalam proses kegiatan pembelajaran untuk mencapai kompetensi pelajaran yang akan dilaksanakan dalam proses kegiatan pembelajaran untuk mencapai kompetensi pembelajaran yang telah ditetapkan. Kegiatan ini merupakan langkah awal yang harus ditempuh guru dalam melaksanakan kegiatan pembelajaran. Guru sebagai tenaga pengajar harus memiliki kemampuan dan berkemampuan baik sebagai perencana/perancang pembelajaran. Guru sebagai perancang pembelajaran bertugas membuat rancangan program pembelajaran yang menjadi tanggung jawabnya sesuai dengan kompetensi yang telah ditetapkan. Lebih lanjut Wahyuni dan Ibrahim mengatakan salah satu perencanaan pembelajaran yang penting bagi guru adalah RPP. Setiap guru dituntut untuk bisa merancang atau merencanakan pembelajaran sebelum proses pembelajaran itu dilaksanakan; karena pada hakikatnya perencanaan atau perancangan RPP bertujuan merancang pengalaman belajar siswa untuk mencapai tujuan pembelajaran. Alasan pentingnya membuat RPP yaitu dapat menolong guru untuk 
memikirkan pelajaran sebelum pelajaran itu diajarkan sehingga kesulitan belajar dapat diramalkan dan jalan keluarnya dapat dicari. Guru dapat mengorganisasi fasilitas, strategi pembelajaran, perlengkapan, alat bantu pengajaran, waktu dan isi dalam rangka untuk mencapai tujuan belajar seefektif mungkin serta menghubungkan tujuan dan prosedur kepada tujuan keseluruhan dari mata pelajaran yang diajarkan.

Selanjutnya, berkaitan dengan perencanaan penggunaan strategi pembelajaran yang variatif dalam proses pembelajaran merupakan salah satu pendekatan yang harus dikuasai oleh seorang guru. Karena strategi pembelajaran terdiri atas teknik dan metode atau prosedur yang menjamin siswa untuk mencapai tujuan pembelajaran. Seperti yang diungkapkan oleh Gerlach dan Ely, bahwa strategi pembelajaran adalah cara yang dipilih untuk menyampaikan materi pelajaran dalam lingkungan pengajaran tertentu, yang dapat meliputi sifat, lingkup dan urutan kegiatan yang dapat memberikan pengalaman belajar kepada siswa. Sejalan dengan itu, Grooper juga mengemukakan bahwa strategi pembelajaran terdiri atas semua komponen materi pengajaran dan prosedur yang akan digunakan untuk membantu siswa mencapai tujuan pengajaran tertentu (dalam Hamdani, 2011:19).

Sehingga Hamdani (2011:19) mempertegas bahwa peranan strategi pengajaran lebih penting apabila guru mengajar siswa yang berbeda dari segi kemampuan, pencapaian, kecenderungan, serta minat. Hal tersebut karena guru harus memikirkan strategi pengajaran yang mampu memenuhi kemampuan semua siswa. Disini, guru tidak saja harus menguasai kaidah dalam mengajar, tetapi yang lebih penting adalah mengintegrasikan serta menyusun kaidah-kaidah itu untuk membentuk strategi pengajaran yang paling berkesan dalam pengajarannya.

Kemudian hasil penelitian pada poin kedua yang berkenaan dengan kemampuan guru dalam mengimplementasikan pembelajaran yang berbasis PAIKEM sejalan dengan yang dikatakan oleh Herbart (dalam Sukarman, 2003:27), apersepsi adalah memperoleh tanggapan-tanggapan baru dengan bantuan tanggapan yang telah ada. Jadi menurut Herbart (dalam Sukarman, 2003:27-29) bahwa apa yang telah diketahui dapat digunakan untuk memahami sesuatu yang belum diketahui. Dengan kata lain bahwa apersepsi adalah menghubungkan pelajaran lama dengan pelajaran baru, sebagai batu loncatan sejauh mana peserta didik menguasai pelajaran lama sehingga dengan mudah menyerap pelajaran baru. Dengan demikian fungsi apersepsi dalam kegiatan pembelajaran adalah untuk mengaitkan apa yang telah diketahui atau di alami peserta didik dengan apa yang akan dipelajari. Secara lebih luas, Chatib (2012) mengungkapkan apersepsi sebagai stimulus khusus pada awal belajar yang bertujuan meraih perhatian dari peserta didik. Jadi apersepsi itu membangkitkan minat dan perhatian untuk sesuatu. Apersepsi juga dimaknai sebagai menciptakan kondisi alfa, yaitu kondisi terbaik untuk belajar peserta didik sebab pada kondisi alfa, neuron sedang berada dalam suatu keseimbangan. Selain melakukan apersepsi di awal pembelajaran, dalam melaksanakan pembelajaran yang bermakna dan menyenangkan, guru harus mampu menganalogikan secara sederhana pelajaran yang diberikan dengan kehidupan dunia nyata yang dialami oleh siswa. Sependapat dengan hal tersebut, Depdiknas (2002) menegaskan model pembelajaran yang mampu memberikan makna terhadap materi yang dipelajari dan mampu menghubungkannya dengan kenyataan hidup sehari-hari ialah model pembelajaran kontekstual.

Model pembelajaran kontekstual menekankan pada proses keterlibatan siswa secara penuh agar dapat memperoleh makna dari materi yang dipelajari dan mengaitkannya dengan dunia nyata siswa sehingga siswa mampu membuat hubungan antara pengetahuan yang dimiliki dan penerapannya dalam kehidupan mereka sehari-hari. Sagala (2007) juga mengemukakan hal serupa bahwa konsep belajar dengan model pembelajaran kontekstual adalah membantu guru mengaitkan materi yang diajarkannya dengan situasi dunia nyata siswa dan mendorong siswa membuat hubungan antara pengetahuan yang dimilikinya dan penerapannya dalam kehidupan mereka sehari-hari. Pembelajaran kontekstual sangat efektif dalam meningkatkan kecakapan berpikir secara rasional, kecakapan berpikir sosial dan penguasaan konsep siswa.

Pengaitan materi pelajaran dengan kehidupan sehari-hari siswa juga akan lebih konkrit adanya jika didukung dengan penggunaan dan pemanfaatan media dan alat peraga yang relevan dalam proses pembelajaran. Para guru dituntut agar mampu menggunakan alat-alat yang dapat disediakan oleh sekolah, dan tidak tertutup kemungkinan bahwa 
alat-alat tersebut sesuai dengan perkembangan dan tuntutan zaman. Guru sekurang-kurangnya dapat menggunakan alat yang murah dan sederhana dalam proses pembelajaran guna keoptimalan dalam upaya mencapai tujuan pengajaran yang diharapkan. Sejalan dengan hal tersebut, Arsyad (2014:4) mengungkapkan media pembelajaran adalah komponen sumber belajar atau wahana fisik yang mengandung materi instruksional di lingkungan siswa yang dapat merangsang siswa siswa untuk belajar. Sependapat dengan itu, Hamalik (1986) dalam Arsyad, (2014:19) juga mengungkapkan penggunaan media pembelajaran dalam proses pembelajaran dapat membangkitkan keinginan dan minat yang baru, membangkitkan motivasi dan rangsangan kegiatan belajar, dan bahkan membawa pengaruh-pengaruh psikologis terhadap siswa; dimana siswa dapat diajak atau diberikan secara konkrit hal-hal yang berkaitan dengan pembelajaran sehingga memungkinkan siswa untuk berpikir secara lebih nyata dan rasional.

Penggunaan media dan alat peraga dalam pembelajaran juga memerlukan kemampuan dan kreativitas yang ekstra dari seorang guru. Diperlukan keterampilan dalam berinovasi untuk membuat suatu media yang berdampak pada pembelajaran yang menyenangkan bagi anak didik. Pengkondisian perhatian anak didik juga erat kaitannya dengan keberhasilan pencapaian tujuan pembelajaran. Ketika anak didik telah terkondisi dengan baik, sangat jelas bahwa kemungkinan besar fokus dan perhatiannya juga sangat besar dan termotivasi dalam mengikuti pembelajaran di kelas. Serangkaian aktivitas yang berbasis gerakan tubuh sederhana atau dapat disebut dengan "senam" dapat dimanfaatkan untuk merangsang konsentrasi siswa dalam mengikuti pembelajaran sehingga memberikan pikiran yang lebih jernih, kemampuan daya ingat meningkat, menjadi lebih bersemangat dan lebih kreatif. Sejalan dengan itu, Denisson (2009) mengatakan kebermanfaatan senam otak (brain gym) bagi peserta didik yaitu dapat merangsang kemampuan berbahasa dan daya ingat meningkat, menjadi lebih bersemangat, lebih kreatif dan efisien, serta merasa lebih sehat. Lebih lanjut, Denisson (2009) mengungkapkan bahwa otak sebagai pusat kegiatan tubuh akan mengaktifkan seluruh organ dan sistem tubuh melalui pesan-pesan yang disampaikan melewati serabut saraf secara sadar maupun tidak sadar sehingga meningkatkan konsentrasi dan pemusatan pikiran terhadap suatu aktivitas atau pekerjaan tertentu.

Hasil penelitian pada poinketiga yang berkenaan dengan kemampuan guru dalam mengevaluasi hasil belajar yang sesuai dengan kemampuan peserta didik sejalan dengan yang dungkapkan oleh Harijadi (2012) bahwa RPP sekurang-kurangnya memuat tujuan pembelajaran, materi pelajaran, metode pengajaran, sumber belajar dan penilaian hasil belajar. Jadi, dalam melaksanakan proses pembelajaran sampai pada evaluasi pembelajaran guru tidak perlu lagi membuat atau menyusun teknik evaluasi seperti apa yang ingin digunakan karena semua sudah terencana dengan baik dalam RPP yang dibuat sebelumnya. Lebih lanjut, Osnal, dkk (2016) menyebutkan guru memiliki kompetensi di dalam mengkontruksi tes karena tes dipakai sebagai alat untuk mengukur ketercapaian pembelajaran. Hasil belajar merupakan prestasi yang dapat ditunjukkan dalam bentuk simbol angka oleh siswa setelah mengikuti proses pembelajaran. Jenis hasil tes belajar seperti: post tes, formatif tes, diagnostik tes dan sumatif tes. Sejalan dengan itu, Widoyoko (2013:46) juga menegaskan bahwa bentuk tes yang digunakan pada lembaga pendidikan dapat dikategorikan menjadi dua, yaitu tes subjektif dan tes objektif. Kedua tes ini sama-sama memiliki manfaat dan peranan dalam menilai hasil belajar anak didik. Hal ini dikarenakan, untuk tes subjektif pada umumnya bersifat uraian yang diperuntukkan untuk melihat sejauhmana kemampuan anak didik dalam mendeskripsikan dan menganalisis suatu persoalan yang diberikan kepadanya. Sedangkan tes objektif pada umumnya merupakan bentuk tes yang mengandung kemungkinan jawaban atau respons yang harus dipilih oleh peserta tes; artinya tes sobjektif ini bersifat objektif sesuai dengan objek jawaban atau respons yang diberikan oleh peserta tes.

Berkaitan dengan pemanfaatan hasil evaluasi sebagai feedback dalam pemberian pelajaran selanjutnya sesuai dengan yang diungkapkan oleh Arikunto (2008) dalam Widoyoko (2013:36) bahwa guru maupun pendidik lainnya perlu mengadakan penilaian terhadap hasil belajar siswa karena dalam dunia pendidikan, khususnya dunia persekolahan dimana penilaian terhadap hasil belajar siswa memiliki makna yang penting, baik bagi siswa maupun guru. Lebih lanjut, Widoyoko menegaskan bahwa hasil suatu penilaian tertentu dapat digunakan 
sebagai umpan balik, baik nagi individu yang menempuh tes maupun bagi guru yang berusaha menstransfer kemampuan kepada siswa. Sehingga sangat jelas bahwa proses penilaian juga tidak kalah penting dari proses-proses lainnya dalam pembelajaran terlebih untuk memberikan manfaat dan masukan dalam melaksanakan pembelajaran yang lebih baik ke depannya.

\section{SIMPULAN DAN SARAN}

\section{Simpulan}

Berdasarkan keseluruhan paparan data, temuan penelitian dan pembahasan hasil penelitian, dapat disimpulkan bahwa kemampuan guru dalam merancang/merencanakan RPP, kemampuan guru dalam melaksanakan pembelajaran di kelas, serta kemampuan guru dalam mengevaluasi hasil belajar siswa sudah cukup baik dan sesuai dengan kemampuan peserta didik serta sesuai dengan ketentuan yang berlaku yang diterapkan di sekolah. Kondisi tersebut dapat dikategorikan bahwa kompetensi pedagogik yang dimiliki guru sudah cukup baik, walaupun masih perlu dilakukan pembinaan kepada guru dalam perbaikan proses pembelajaran.

\section{Saran}

Berdasarkan hasil penelitian, disarankan bagi Dinas Pendidikan Kota Palangka Raya diharapkan dapat dijadikan sebagai bahan masukan dan saran dalam upaya memfasilitasi tiap-tiap sekolah, khususnya bai guru-guru untuk lebih mengembangkan kreatifitas dan inovasi guru-guru dalam meningkatkan kompetensi pedagogik yang dimilikinya dalam rangka mencapai kompetensi professional sebagai seorang tenaga pendidik.

Bagi Kepala SDN 5 Menteng Kota Palangka Raya diharapkan: (1) dapat menjadi masukan untuk memfasilitasi guru-guru di sekolah dalam rangka mengembangkan kompetensi pedagogiknya terutama yang berkenaan dengan aspek-aspek: (a) kemampuan membuat perencanaan pembelajaran, (b) kemampuan dalam melaksanakan pembelajaran dengan baik, serta (c) kemampuan dalam mengevaluasi hasil belajar siswa sesuai dengan kemampuan siswa. (2) Memberikan motivasi, pembinaan, serta arahan kepada guru-guru untuk selalu melakukan pembimbingan kepada siswa terutama pada saat menyelesaikan pekerjaan yang sedang diberikan kepada siswa yang bersangkutan.
Bagi guru-guru SDN 5 Menteng Kota Palangka Raya diharapkan: (1) dapat meningkatkan dan mengembangkan kemampuannya dalam merancang / merencanakan pembelajaran sesuai dengan kebutuhan siswanya; sehingga tidak hanya mengandalkan copy paste dari internet, (2) memotivasi diri untuk memanfaatkan media dan alat peraga dengan optimal dalam pembelajaran sehingga memungkinkan peserta didik memperoleh penjelasan yang akurat terkait pembelajaran yang ada, dan (3) senantiasa selalu membimbing siswa dalam proses pembelajaran terutama pada saat menyelesaikan persoalanpersoalan yang diberikan sehingga siswa merasa diperhatikan bukan dibiarkan bekerja sendiri.

\section{DAFTAR RUJUKAN}

Arsyad. 2014. Media Pembelajaran. Jakarta: RajaGrafindo Persada.

Bogdan, R.C. \& Biklen, S.K. 1992. Qualitative Research for Education, second edition. USA: Allyn and Bacon.

Chatib, Munif. 2012. Gurunya Manusia. Bandung: PT. Mizan Pustaka.

Dennison, P. 2009. Brain Gym and Me. Jakarta: PT Grasindo.

Depdiknas, 2002. Pendekatan Kontekstual (Contextual Teaching and Learning). Jakarta: Depdiknas.

Depdiknas. 2004. Standar Kompetensi Guru Pemula SMP-SMA. Jakarta: Departemen Pendidikan dan Kebudayaan Dirjen Pendidikan Tinggi.

Depdiknas. 2005. Undang-Undang Nomor 14 Tahun 2005 tentang Guru dan Dosen. Jakarta: Depdiknas

Hamdani. 2011. Strategi Belajar Mengajar. Bandung: PUSTAKA SETIA.

Harijadi. 2012. Evaluasi Pemanfaatan Rencana Pelaksanaan Pembelajaran pada Kegiatan Pembelajaran di Kelas pada Guru Pemula Sekolah Dasar di Banyuwangi. Jurnal Ilmu Pendidikan Sekolah Dasar, 1 (2): 194-199.

Imron. 2011. Supervisi Pembelajaran Tingkat Satuan Pendidikan. Jakarta: Bumi Aksara.

Indriani. 2015. Kompetensi Pedagogik Guru dalam Mengelola Pembelajaran IPA di SD dan MI, Jurnal FENOMENA, (Online), 7 (1): 17-29, (https://www.uad.ac.id), diakses 8 November 2017). 
Jawing, dkk. 2011. Kepemimpinan Kepala Sekolah dalam Meningkatkan Kompetensi Pedagogik Guru di SMA Negeri 3 Sintang, (Online), (https://www.untan.ac.id), diakses 8 November 2017).

Khofiatun. 2016. Peran Kompetensi Pedagogik Guru dalam Pembelajaran Tematik di Sekolah Dasar,Jurnal Pendidikan, (Online), 1 (5): 984-988, (https://www.um.ac.id), diakses 8 November 2017).

Lativa, dkk. 2016. Meningkatkan Kompetensi Pedagogik dan Profesional Guru SMK Melalui Pemberdayaan Pengembangan Keprofesian Berkelanjutan (PKB). Makalah disajikan pada Seminar Nasional Pendidikan, Universitas Negeri Malang, (Online), (https://www.um.ac. id), diakses 8 November 2017.

Osnal, dkk. 2016. Meningkatkan Kemampuan Guru dalam Menyusun Tes Hasil Belajar Akhir Semester Melalui Workshop di KKG Gugus 02 Kecamatan Sumbermalang Situbondo. Jurnal Pancaran, 5 (1): 67-82.
Sagala, S. 2007. Konsep dan Makna Pembelajaran. Bandung: Alfabeta.

Sagala, S. 2013. Kemampuan Profesional Guru dan Tenaga Kependidikan. Bandung: Alfabeta.

Saryati. 2014. Upaya Peningkatan Kompetensi Pedagogik Guru Sekolah Dasar. Jurnal Administrasi Pendidikan, (Online), 2 (1): 669-831, (https://www.unp.ac.id), diakses 8 November 2017).

Sukarman. 2003. Dasar-Dasar Didaktik dan Penerapannya dalam Pembelajaran. Jakarta: Direktorat Tenaga kependidikan Dikdasmen Depdiknas.

Ulfatin, N. 2014. Metode Penelitian Kualitatif di Bidang Pendidikan: Teori dan Aplikasinya. Malang: Bayumedia Publishing.

Wahyuni dan Ibrahim. 2012. Perencanaan Pembelajaran BahasaBerkarakter. Malang: Refika Aditama.

Widoyoko. 2013. Evaluasi Program Pembelajaran. Yogyakarta: Pustaka Pelajar. 